\title{
Comparison of methods of measurement of the finger flexor muscles' strength through dynamometry and modified manual sphygmomanometer
}

\author{
Comparação dos métodos de mensuração da força muscular dos flexores dos dedos das mãos \\ através da dinamometria manual e esfigmomanômetro modificado
}

\author{
Paulo Roberto Garcia Lucareli¹, Mário de Oliveira Lima ${ }^{2}$, Fernanda Pupio Silva Lima \\ Rafaela Okano Gimenes ${ }^{4}$, Juliane Gomes de Almeida Lucareli ${ }^{5}$, Silvio Antonio Garbelotti Junior 6 \\ Thiago Yukio Fukuda ${ }^{7}$, José Eduardo Pompeu ${ }^{8}$
}

\begin{abstract}
Objective: To evaluate the reproducibility of the modified sphygmomanometer compared to hand dynamometer to measure muscle strength of the flexor muscles of fingers. Methods: We assessed 40 healthy volunteers of both genders, aged between 20 and 55 years, who underwent the muscle strength test in the finger flexor muscles on both hands using two instruments for which the comparison was made between them. Results: After statistical analysis by the paired Student's $t$ test, there was no significant difference between the values obtained in modified sphygmomanometer and hand dynamometer tests in relation to right and left sides $(p>0.05)$. Pearson's coefficient of correlation observed good correlations between them. Conclusions: The modified sphygmomanometer proved to be a reproducible technique for measuring muscle strength of the finger flexor muscles.
\end{abstract}

Keywords: Sphygmomanometers; Physical exertion; Muscle strength dynamometer

\section{RESUMO}

Objetivo: Avaliar a reprodutibilidade do esfigmomanômetro modificado para a mensuração da força muscular dos músculos flexores dos dedos das mãos através da comparação do mesmo com o dinamômetro manual. Métodos: Foram avaliados 40 voluntários saudáveis de ambos os sexos com idade entre 20 e 55 anos que realizaram o teste de força muscular dos músculos flexores dos dedos em ambas as mãos com os dois instrumentos para que fosse feita a comparação entre eles. Resultados: Após análise estatística feita pelo teste $t$ de Student pareado, não foi observada diferença significativa entre os valores obtidos nos testes esfigmomanômetro modificado e dinamômetro manual em relação à lateralidade $(p>0,05)$, assim como, no teste do coeficiente de correlação de Pearson, foram observadas correlações quando analisados os valores obtidos no teste com esfigmomanômetro modificado versus o teste com dinamômetro manual. Conclusões: 0 esfigmomanômetro modificado mostrou ser uma técnica reprodutível para medir força muscular dos músculos flexores dos dedos.

Descritores: Esfigmomanômetros; Esforço físico; Dinamômetro de força muscular

\section{INTRODUCTION}

The hand is a complex organ with several functions. As a grip organ, it is both able to exert strength and hold and handle delicate objects; as a tactile organ, it links the body to the environment, and it also has great importance in verbal communication ${ }^{(1-2)}$.

Handgrip strength is one of the basic and important elements in the study of handling, strength and

\footnotetext{
Study carried out at Centro Universitário São Camilo, São Paulo (SP), Brasil.

PhD; Professor of Department of Master of Science in Rehabilitation Sciences at Universidade Nove de Julho - UNINOVE, São Paulo (SP), Brazil; Senior physiotherapist at the Physical Rehabilitation Clinic of Hospital Israelita Albert Einstein - HIAE, São Paulo, Brazil.

${ }^{2} \mathrm{PhD}$; Lecturer at Universidade do Vale do Paraíba - UNIVAP, São José dos Campos (SP), Brazil.

${ }^{3}$ PhD; Adjunct professor at Universidade do Vale do Paraíba - UNIVAP, São José dos Campos (SP), Brazil.

${ }^{4}$ Master's degree; Assistant professor at Centro Universitário São Camilo, São Paulo (SP), Brazil.

${ }^{5}$ Master's degree; Professor at Universidade Paulista - UNIP, São Paulo (SP), Brazil.

${ }^{6}$ Master's degree; Professor at Centro Universitário São Camilo, São Paulo (SP), Brazil.

Master's degree; Professor at Centro Universitário São Camilo, São Paulo (SP), Brazil.

${ }^{8}$ Master's degree; Adjunct professor of Physical Therapy at Universidade Paulista - UNIP, São Paulo (SP), Brazil; Professor at Centro Universitário São Camilo, São Paulo (SP), Brazil. Corresponding author: Paulo Roberto Garcia Lucareli - Rua Marechal Hermes da Fonseca, 91, apto 42 - Santana - CEP 02020-000 - São Paulo (SP), Brasil - Tel.: 11 2151-2271 - e-mail: plucareli@hotmail.com Received on Jun 19, 2009 - Accepted on Apr 12, 2010
} 
movement abilities of the hands, since they are essential for performing the activities of daily living (ADL), being used in $45 \%$ of all the ADL performed during the day, except for locomotor activities ${ }^{(3-4)}$.

Assessment of muscle strength has been subject of studies in different fields of knowledge. The medical literature shows that different subjective methods, such as manual muscle testing and objective methods, such as the hand-held and isokinetic dynamometer, have been used to measure this physical valence ${ }^{(5-6)}$.

The frequent use of the manual muscle strength test is mostly attributed to the easiness with which the technique is performed in a short period of time and with no specific equipment cost. However, accuracy and sensitivity of this method are relatively poor.

The modified sphygmomanometer (MS) is an alternative instrument that is currently used to assess muscle strength. A MS is built when a conventional device is adapted, with removal of its external velcro, and folding of the cuff in three parts followed by placement into an inelastic bag $^{(6-9)}$.

Although it is not well known in clinical practice, the MS assessment method seems to be a relevant and reliable option to estimate the strength of muscle groups. It is a low-cost instrument with easy handling that can be found in any drugstore or a store specialized in medical equipment. However, to obtain good results, the MS must be calibrated before each measurement.

\section{OBJECTIVE}

The objective of this study was to evaluate the reproducibility of modified sphygmomanometer to measure muscle strength of finger flexor muscles by comparing it with the hand dynamometer (MD).

\section{METHODS}

\section{Patients}

A total of 40 healthy volunteers of both genders and aged between 20 and 55 years participated in this experiment; they all agreed and signed the informed consent form, as well as met the inclusion and exclusion criteria.

The inclusion criteria entailed the absence of orthopedic or musculoskeletal diseases or dysfunctions, no previous surgery in their upper limbs, absence of rheumatologic or neurological diseases, absence of pain in the upper limbs leading to test limitation, in addition to not presenting limitation in the range of movements in the upper limbs. Volunteers who presented any of the criteria described above were excluded from the study.
The study was carried out at the Mechanotherapy Laboratory of Centro Universitário São Camilo, São Paulo, Brazil.

The following were used in this study: an aneroid sphygmomanometer (Solidor ${ }^{\circledR}$ - São Paulo, Brazil) (Figure 1) which was modified for the test and calibrated before each measurement; a hand-held dynamometer (Sammons Preston ${ }^{\circledR}$ ) (Figure 2), a table, two stable chairs without arms positioned on each side of the table for measurement of both hands.

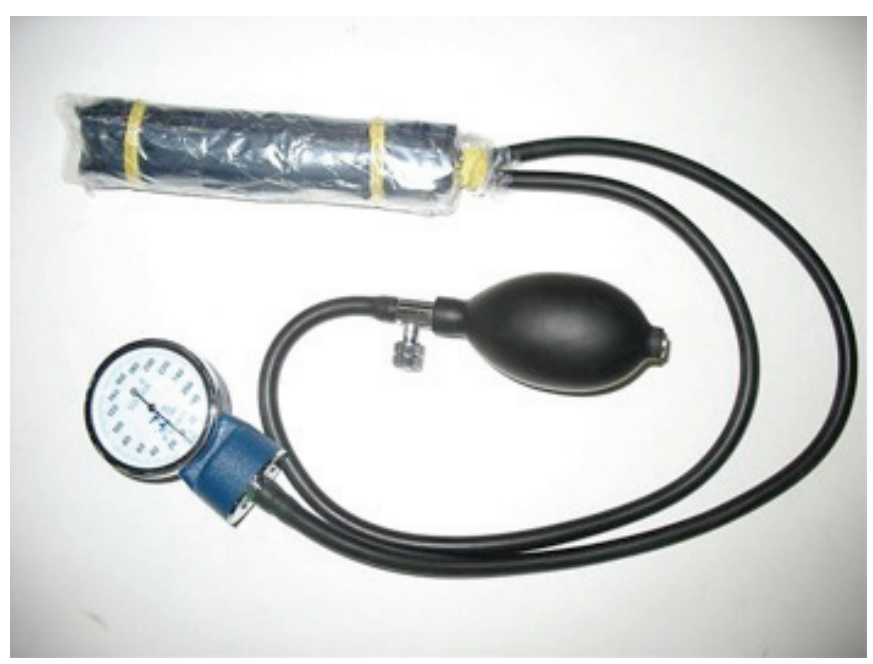

Figure 1. Modified sphygmomanometer

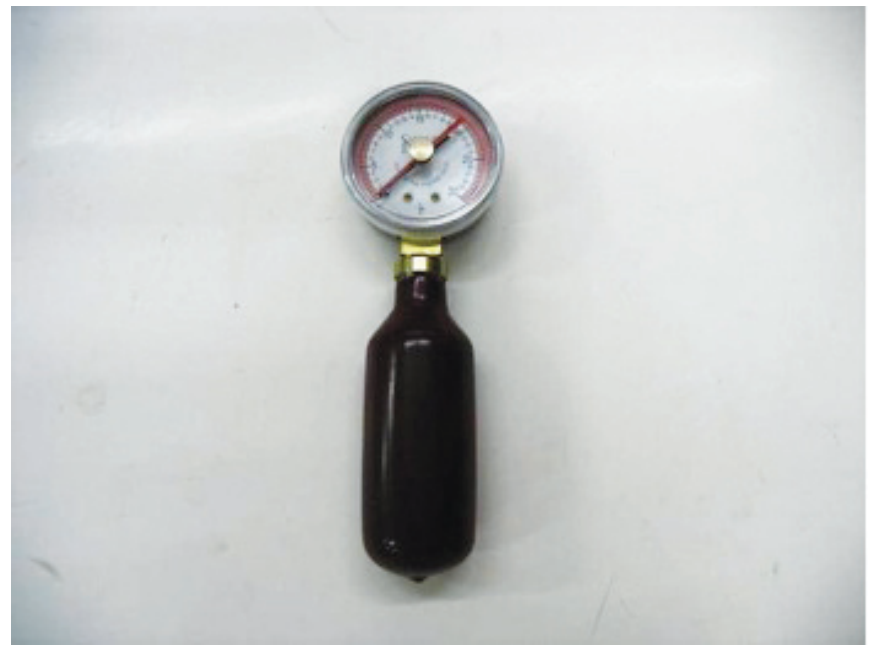

Figure 2. Manual dynamometer

\section{Procedure}

After approval by the Research Ethics Committee, the volunteers underwent a muscle strength test of the flexor digitorum superficialis and flexor digitorum profundus, flexor pollicis longus, flexor pollicis brevis fifth flexor, by means of hand dynamometry and MS by a blinded examiner who was trained to carry out the tests. 
The volunteers were positioned in a chair with the arm in a $90^{\circ}$ flexion on the table where the hand remained out of the table; the hip and knees remained approximately in a $90^{\circ}$ angle flexion.

The test was performed in accordance with the muscle strength test for the muscles mentioned above, described by Kendall ${ }^{(5)}$, in which the volunteer remains seated to undergo the test and performs the contraction in a gripping (palmar closure) movement, in a way that the whole finger length grasps the MS and/or hand-held dynamometer.

The instruments were zeroed before each measurement, placed in the volunteer hand and, upon the examiner command (simple and precise), the volunteer would perform the palmar closure, and the value obtained in the instrument was recorded. Subsequently, the same procedure was performed on the other hand, and after a three-minute interval the test with the next instrument was restarted. The test was carried out three times with each instrument, and the mean value was used in the study.

The selection of the instrument for the test start was at random, as well as the choice of the hand; some volunteers started with the modified sphygmomanometer and others with the hand dynamometer. If the first volunteer had performed the first test with MS, the second volunteer would perform it with hand dynamometer, and this sequence was maintained until the end of tests.

After collection, data was stored in computer files for further statistical analysis using the Graph Pad software, version 5.0 demo.

\section{RESULTS}

The values obtained in the tests are shown in Table 1 . Results of tests performed with hand dynamometer and MS are displayed in graphs (Figure 3).

Table 2 shows that, after statistical analysis with paired Student's $t$-test, no significant difference was

Table 1. Distribution of means and standard deviations obtained after tests with $\mathrm{MD}$ and MS

\begin{tabular}{lcc}
\hline Upper limb & MD $(\mathbf{m m H g})$ & MS $(\mathbf{m m H g})$ \\
\hline Left & $500.82 \pm 150.95$ & $91.7 \pm 23.19$ \\
Right & $477.04 \pm 127.91$ & $92.1 \pm 20.02$ \\
\hline
\end{tabular}

MD: manual dynamometer; MS: modified sphygmomanometer.

Table 2. Distribution of values obtained after statistical analysis through the Students $t$-test and Pearsons correlation coefficient

\begin{tabular}{lcccc}
\hline & \multicolumn{2}{c}{ LUL versus RUL } & \multicolumn{2}{c}{ MS versus MD } \\
\cline { 2 - 5 } & MS & MD & RUL versus RUL & LUL versus LUL \\
\hline $\begin{array}{l}\text { r correlation } \\
\begin{array}{l}\text { Student's } t \text {-test } \\
(p<0.05)\end{array}\end{array}$ & - & - & 0.91 & 0.86 \\
\hline
\end{tabular}

LUL: left upper limb; RUL: right upper limb; MD: manual dynamometer; MS: modified sphygmomanometer.

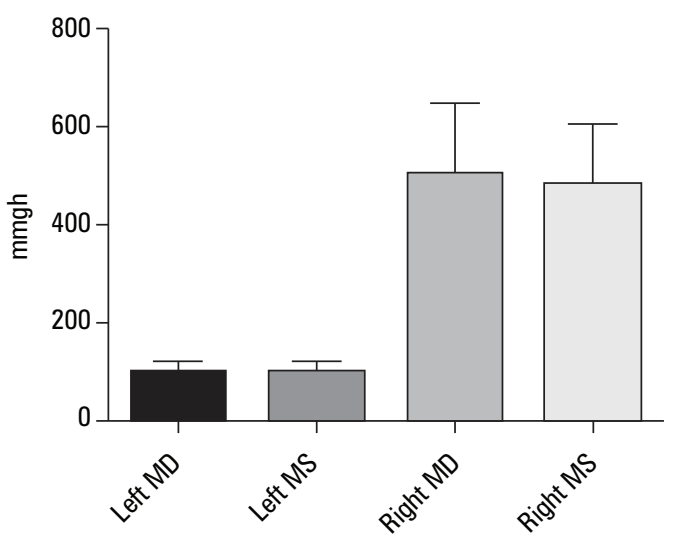

Figure 3. Distribution of values obtained after performing MS and MD in the left and right sides

observed between the values obtained in the MS and hand dynamometer tests in regard to the left and right upper limbs $(\mathrm{p}>0.05)$. On the other hand, in the Pearson's correlation coefficient test, we observed correlations when analyzing the values obtained between the MS versus hand dynamometer test (Figure 4).

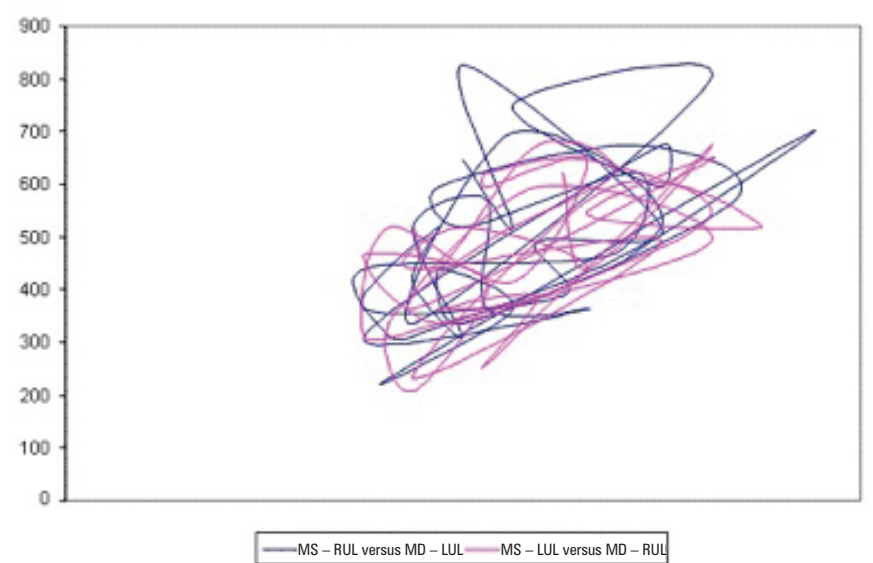

Figure 4. Distribution of the values obtained after Pearson's coefficient of correlation in relation to differences between modified sphygmomanometer and hand dynamometer test to right (R) and left (L) sides.

\section{DISCUSSION}

It is known that the most used test in clinical practice is the hand muscle test for being fast and with no operational cost; however, the use of a sphygmomanometer is another low-cost, easy-handling tool that can be inserted in the context of physical rehabilitation.

Statistical data show a good correlation when analyzing the values obtained between the test with modified sphygmomanometerversus hand dynamometer as comparing the right and left upper limbs.

The current literature is still scarce in regard to the quantity of controlled and randomized studies about reliability and efficiency of the modified sphygmomanometer. However, Helewa et al. ${ }^{(10)}$ had 
already stated that the muscle strength assessment technique with this instrument offered quantitative and objective measurements that were more sensitive to the different strength patterns; they also assured that the modified sphygmomanometer presents a good safety level and can be applied in, at least, 24 muscle groups.

Delgado et al. ${ }^{(6)}$ used the modified sphygmomanometer to assess the strength of extensor and flexor muscles of the knee in 31 military individuals of both genders. The results showed differences of strength between the anterior and posterior groups of the knee joint in the studied angles $\left(120^{\circ}\right.$ and $180^{\circ}$ of knee extension and $30^{\circ}$ and $90^{\circ}$ of knee flexion). They concluded that the technique of strength measurement through MS offered quantitative and objective measurements and also evidenced its use as a lowcost and practical method that could be applied as a comparison parameter.

By using a modified sphygmomanometer to assess the isometric strength of elbow extensors and hip extensors in 36 hospitalized patients between the ages of 62 and 95 years, Kaegi et al. ${ }^{(9)}$ suggested that this instrument is easy to use and requires little application time; it also has a low cost and the additional factor of being practical, hand-held, thus allowing the assessment of volunteers in different sites (clinics, hospitals and at home) and with market purchase availability.

Perossa et al. ${ }^{(11)}$, in a study carried out with 80 volunteers, used the modified sphygmomanometer to measure the muscle strength of extensor, flexor, adductor and abductor muscles of the hip and also the extensor, flexor and external and internal rotators of the shoulder. Their results showed a high grade of reliability for the hip muscles with a variation of 0.94-0.97.

Sometimes, the individuals may exceed the upper limit of the MS, which is $300 \mathrm{mmHg}$, thus making assessment impossible. However, Bohannon and Lusardi $^{(12)}$ and Bohannon ${ }^{(13)}$ suggested a curvilinear relation above $210 \mathrm{mmHg}$ when they assessed the muscle strength of the flexor muscles of the elbow in 36 healthy volunteers through MS and hand-held dynamometer. These authors concluded that it is necessary to have precautions when the strength measurement is required for stronger volunteers and that this instrument may not be the best choice to obtain accurate strength measurements.

Medical literature has evidence pointing to the importance of having strength measurements on which we can rely to assess the patients. Several methods were presented, but we believe care must be exercised when selecting an assessment method. In our study, the MS proved to be a good method for assessing the muscle strength in the flexor muscles of the fingers; however, no similar paper using this instrument to measure the handgrip strength was found in the medical literature.

\section{CONCLUSIONS}

MS proved to be a reproducible technique to measure the muscle strength of the flexor muscles in the fingers of the assessed subjects.

It is suggested that the MS reproducibility be tested in other muscle groups since there is no consensus in the literature about reliability.

\section{REFERENCES}

1. Moreira D, Godoy JR, Silva W Jr. Estudo sobre a realização da preensão palmar com a utilização do dinamômetro: considerações anatômicas e cinesiológicas. Fisioter Brasil. 2001;2(5):295-300.

2. Moreira D, Godoy JR, Silva W Jr. Anatomia e cinesiologia clínica do aparelho do movimento. São Paulo: Thesaurus; 2004.

3. Durward BR, Baer GD, Rowe PJ. Movimento funcional humano: mensuração e análise. Barueri (SP): Manole; 2001.

4. Reider B. 0 Exame físico em ortopedia. Rio de Janeiro: Guanabara Koogan; 2001.

5. Kendall FP, McCreary EK, Provance PG. Músculos: provas e funções. 4a ed. Barueri (SP): Manole; 1995.

6. Delgado C, Fernandes Filho JF, Barbosa FP, Oliveira HB. Utilização do esfigmomanômetro na avaliação da força dos músculos extensores e flexores da articulação do joelho em militares. Rev Bras Med Esporte. 2004;10(5):362-6.

7. Heintz S, Gutierrez-Farewik EM. Static optimization of muscle forces during gait in comparison to EMG-to-force processing approach. Gait Posture. 2007;26(2):279-88.

8. Noreau L, Vachon J. Comparison of three methods to assess muscular strength in individuals with spinal cord injury. Spinal Cord. 1998;36(10):716-23.

9. Kaegi C, Thibault MC, Giroux F, Boubonnais D. The interrater reliability of force measurements using a modified sphygmomanometer in elderly subjects. Phys Ther. 1998;78(10):1095-103.

10. Helewa A, Goldsmith $\mathrm{CH}$, Smythe HA. The modified sphygmomanometeran instrument to measure muscle strength: a validation study. J Chron Dis. 1981;34(7):353-61.

11. Perossa D, Dziak M, Vernon HT, Hayashita K. The intra-examiner reliability of manual muscle testing of the hip and shoulder with a modified sphygmomanometer: a preliminary study of normal subjects. J Can Chiropr Assoc. 1998;42(2):73-82.

12. Bohannon RW, Lusardi MM. Modified sphygmomanometer versus strain gauge hand-held dynamometer. Arch Phys Med Rehabil. 1991;72(11):911-4.

13. Bohannon RW. Hand-grip dynamometry provides a valid indication of upper extremity strength impairment in home care patients. J Hand Ther. 1998;11(4):258-60. 